\title{
INOVASI PENDIDIKAN: METODE PEMBELAJARAN MONOTON KE PEMBELAJARAN VARIATIF (METODE CERAMAH PLUS)
}

\author{
Satriani \\ IAIN Manado \\ satrianiqwee@gmail.com
}

\begin{abstract}
Education is the spearhead of a country. The more developed a country level will make the country more advanced. For that an educator should bias innovation in education. One of them by choosing teaching methods or create new methods appropriate to the learners so that the learning process can take place effectively and deliver results as expected. Teachers are required to have four competency in performing their duties. One of them is professional competence. For that, an educator must have the ability to keep abreast of the times. Today, the world is faced with rapid technological developments. Educators genius should be able to see it and take advantage of technology advances. However, the reality is the majority of educators can not develop their skills, especially regarding his duties as the subject of the learning process. Until finally learning activities becomes a difficult thing. This is evident from the number of educators both teachers and lecturers who use learning methods that are tedious (only one method such as a lecture).
\end{abstract}

Keywords:educator, education, teaching methods and educational purposes.

\begin{abstract}
Abstrak
Pendidikan merupakan ujung tombak suatu negara. Semakin maju pendidikan suatu negara akan menjadikan negara tersebut semakin maju. Untuk itu seorang pendidik seharusnya bias melakukan inovasi dalam pendidikan. Salah satunya dengancara memilih metode pembelajaran atau menciptakan metode baru yang tepat untuk para peserta didiknya agar proses pembelajaran bisa berlangsung efektif dan memberikan hasil sesuai dengan yang diharapkan. Pendidik dituntut untuk memiliki empat kompetensi dalam menjalankan tugasnya.Salah satu diantaranya adalah kompetensi profesionalisme.Untuk itu, seorang pendidik harus memiliki kemampuan mengikuti perkembangan zaman.Hari ini, dunia dihadapkan dengan perkembangan teknologi yang begitu pesat.Pendidik yang jenius seharusnya bisa melihat itu dan memanfaatkan kemajuan teknologi yang ada. Namun, kenyataan yang ada sebagian besar pendidik tidak bisa mengembangkan keahlian mereka khususnya mengenai tugasnya sebagai subjek proses pembelajaran. Hingga akhirnya kegiatan pembelajaran menjadi suatu hal yang sulit.Ini terlihat dari banyaknya pendidik baik guru maupun dosen yang menggunakan metode pembelajaran yang monoton (hanya satu metode saja seperti metode ceramah).
\end{abstract}

Kata kunci: pendidik, pendidikan, metode pembelajaran dan tujuan pendidikan. 


\section{A.Pendahuluan}

Pendidikan dewasa ini dihadapkan dengan begitu banyak masalah.Masalah-masalah yang tejadi bukan hanya diakibatkan dari satu faktor saja tapi dari beragam faktor. Keragaman faktor tersebut mengakibatkan semakin kompleks pula masalah yang harus dihadapi oleh dunia pendidikan saat ini.Faktor yang paling urgen adalah sikap dan pemahaman pendidik itu sendiri.

Pendidik memiliki tugas yang sangat kompleks yakni bertugas untuk transfer of knowledge dan transfer of value. Untuk itu, seorang pendidik seharusnya memiliki keempat kompetensi yaitu: kompetensi pedagogik, kompetensi kepribadian, kompetensi sosial dan kompetensi profesional. Hanya saja sebagian guru sudah kehilangan jati diri hingga tidak lagi menjadi idola/panutan. Bukan hanya itu, sebagian pendidik juga mengalami kesulitan di dalam penggunaan metode pembelajaran karena masih menggunakan cara yang lama (metode ceramah).

Untuk itu, tulisan ini akan membahas bagaimana cara untuk memudahkan para pendidik untuk memilih metode pembelajaran yang lebih variatif agar tujuan pembelajaran yang diharapkan bisa tercapai. Tulisan ini merupakan library research dan ditunjang dengan hasil pengalaman secara langsung penulis sebagai pendidik yang terlibat langsung dalam proses pembelajaran.

\section{B. Pengertian Metode Ceramah Plus}

Sebelum penulis lebih jauh menjelaskan tentang apa itu metode Ceramah Plus, terlebih dahulu penulis akan menjelaskan tentang Metode Ceramah itu sendiri. Masalah Metode Ceramah Plus tidak terlepas dari Metode Ceramah itu sendiri karena Metode Ceramah Plus ini adalah kombinasi antara Metode Ceramah dengan metodemetode pembelajaran yang lainnya.

Adapun defenisi Metode Ceramah adalah metode yang dilakukan guru dalam menyampaikan bahan pelajaran di dalam kelas secara lisan.Interaksi guru dan peserta didik banyak menggunakan bahasa lisan.Dalam metode ini yang mempunyai peran utama adalah guru. ${ }^{1}$

Sedangkan menurut Winarno Surachmad ceramah adalah penerangan dan penuturan secara lisan oleh guru terhadap kelas.Dalam pelaksanaan ceramah untuk menjelaskan uraiannya, guru dapat menggunakan alat-alat pembantu seperti gambargambar.Peranan murid dalam metode ceramah adalah mendengarkan dengan teliti serta mencatat hal-hal yang penting yang dikemukakan oleh guru. ${ }^{2}$

Jadi, metode Ceramah Plus adalah hasil kombinasi antara metode ceramah dengan metode-metode yang lain. Dalam metode ceramah ini, dalam pelaksanaannya selalu menggunakan metode ceramah kemudian diselingi atau ditambah/digabung dengan metode yang lain sehingga proses pembelajaran berlangsung efektif dan efesien.

\section{Beberapa Bentuk Metode Ceramah Plus}

Metode ceramah Plus hadir pada saat metode ceramah sudah dianggap tidak efesien lagi digunakan dalam proses pembelajaran. Hal ini dikarenakan melihat begitu banyak kekurangan/kelemahan yang dimiliki oleh metode Ceramah itu sendiri. Adapun kelemahan metode Ceramah ini yaitu:

1. Rumusan Tujuan Instruksional yang sesuai hanya sampai dengan tingkat comprehension.

Ahmad Sabri, Strategi Belajar Mengajar \& Micro Teaching (Cet. II; Padang: PT. Ciputat Press, 2007), h. 49.

2 Winarno Surachmad, Metodologi Pengajaran Nasional(Bandung: CV. Jemmars), h. 76. 
2. Hanya cocok untuk kemampuan kognitif.

3. Komunikasi cenderung satu arah (one way).

4. Sangat bergantung pada kemampuan komunikasi verbal penyaji.

5. Ceramah yang kurang inspiratif akan menurunkan antusias belajar peserta. $^{3}$

Meskipun metode ceramah sering dianggap biang keladi yang menimbulkan penyakit "verbalisme" dan budaya "bungkam" di kalangan peserta didik, namun kenyataannya metode tersebut masih populer di mana-mana. Hanya, sebelum metode tersebut digunakan guru tentu perlu melakukan modifikasi atau penyesuaian seperlunya. Langkahlangkah yang dapat ditempuh dalam memodifikasi atau menyesuaikan metode ceramah, antara lain ialah dengan kiat pemaduan (kombinasi) antara metode tersebut dengan metode-metode lainnya. Dari kiat pemaduan ini kita dapat memunculkan ragam metode ceramah baru yang berbeda dari aslinya, atau disebut dengan "metode ceramah plus".

Metode ceramah tersebut dapat terdiri atas banyak metode campuran. Oleh karena itu, penulis akan menyajikan beberapa macam bentuk metode Ceramah Plus yaitu antara lain sebagai berikut:

1. Metode Ceramah Plus Tanya Jawab dan Tugas (CPTT)

Seperti yang telah disinggung dalam uraian-uraian sebelumnya, metode ceramah ternyata baru akan membuahkan hasil pembelajaran peserta didik yang memuaskan apabila didukung dengan metode lain di samping alat-alat peraga yang sesuai dengan kebutuhan. Oleh karena itu, perlu adanya gagasan penganekaragaman metode ceramah plus,

\footnotetext{
${ }^{3}$ Abdorrakhman Gintings, Esensi Praktis Belajar \& Pembelajaran (Cet. II; Bandung: Humaniora, 2008), h. 42.

${ }^{4}$ Muhibbin Syah, Psikologi Pendidikan dengan Pendekatan Baru (Cet. VIII; Bandung: PT. Remaja Rosdakarya, 2003). h. 210.
}

antara lain seperti metode "ceramah plus Tanya jawab dan Tugas" (CPTT) ini.

Dipandang dari sudut namanya saja metode tersebut jelas merupakan kombinasi antara metode ceramah, metode tanya jawab dan pemberian tugas. Implementasi (cara melaksanakan) metode campuran ini idealnya dilakukan secara tertib, yakni:

a. Penyampaian uraian materi oleh guru,

b. Pemberian peluang bertanya jawab antara guru dan peserta didik.

c. Pemberian tugas kepada para peserta didik.

Namun demikian, tidak tertutup kemungkinan bagi guru untuk memulai penggunaan metode CPTT tersebut dengan tanya jawab. Dalam hal ini, kegiatan Tanya jawab tersebut dapat berstatus pre test dalam lingkup apersepsi.

Untuk memantapkan penguasaan peserta didik atas materi yang telah disajikan guru, maka pada tahap terakhir pembelajaran, para peserta didik seyogianya diberi tugas baik bersifat individual maupun kelompok, tergantung kebutuhan. Tugas ini dapat berupa: penyusunan reviu (review), penyusunan resume (ikhtisar), atau tugas lain yang dapat dilakukan para peserta didik di luar kelas umpamanya di laboratorium atau di perpustakaan, atau di rumah masingmasing.

Selanjutnya dalam memberi tugas, guru sangat dianjurkan memperhatikan hal-hal sebagai berikut.

a. Tugas yang diberikan harus berhubugan erat dengan materi pelajaran yang telah disajikan.

b. Tugas yang diberikan harus sesuai dengan kesanggupan ranah cipta dan rasa karsa peserta didik.

c. Tugas yang diberikan harus sesuai dengan kesanggupan ranah rasa peserta didik, dalam arti tidak berlawanan dengan sikap dan perasaan batinnya, sehingga ia 
dapat melaksanakan tugas tersebut dengan senang hati.

d. Tugas yang diberikan harus jelas baik jenis, volume, maupun atas waktu penyelesaiannya (Daradjat, 1985). ${ }^{5}$

Mengingat ceramah banyak segi yang kurang menguntungkan, maka penggunaannya harus didukung dengan alat dan media atau dengan metode lain. Karena itu, setelah guru memberikan ceramah, maka dipandang perlu untuk memberikan kesempatan kepada peserta didiknya mengadakan tanya jawab. Tanya jawab ini diperlukan untuk mengetahui pemahaman peserta didik terhadap apa yang telah disampaikan guru melalui metode Ceramah. Untuk lebih memantapkan penguasaan peserta didik terhadap bahan yang telah disampaikan, maka pada tahap selanjutnya peserta didik diberi tugas, misalnya membuat kesimpulan hasil ceramah, mengerjakan pekerjaan rumah, diskusi, dan sebagainya. ${ }^{6}$

Jadi, hasil dari kombinasi metode ceramah yang pertama ini adalah metode ceramah plus Tanya jawab dan tugas. Ketiga metode ini dilakukan dalam satu kali pertemuan di mana setelah guru memberikan atau menyajikan bahan ajar dengan lisan (Metode Ceramah) kemudian guru bertanya kepada peserta didikataukah guru memberikan kesempatan kepada peserta didik untuk bertanya seputar materi pelajaran, setelah itu guru memberikan tugas kepada peserta didik misalnya tugas rumah.

2. Metode Ceramah Plus Diskusi dan Tugas (CPDT)

Berbeda dengan aplikasi metode ceramah plus yang pertama, metode CPDT ini hanya dapat dilakukan secara tertib sesuai dengan urutan pengkombinasiaannya.Maksudnya, pertama-tama guru menguraikan materi

\footnotetext{
${ }^{5}$ Ibid., h. 211.

${ }^{6}$ Syaiful Bahri Djamarah, Aswan Zain, Strategi Belajar Mengajar(Cet. III; Jakarta: PT. Rineka Cipta, 2006), h. 98.
}

pelajaran, kemudian mengadakan diskusi, dan akhirnya memberi tugas. ${ }^{7}$

Penyelenggaraan uraian/ceramah dalam konteks metode ceramah plus ini dimaksudkan untuk memberikan informasi atau penjelasan mengenai pokok bahasan dan topik atau agenda masalah yang akan didiskusikan. Jadi, pada tahap ini guru mejalankan fungsinya sebagai indikator (pemberi masalah yang harus dibicarakan dalam forum diskusi).Sudah tentu, alokasi waktu untuk ceramah harus diatur sedemikian rupa agar kegiatan diskusi memperoleh waktu yang cukup. Pengaturan alokasi waktu ini sangat penting memperoleh perhatian guru, karena akan mempengaruhi jalannya diskusi yang akan dilaksanakan peserta didik yang mungkin akan tergesagesa, kalau waktuya kurang memadai.

Seusai diskusi, para peserta didik diberi tugas-tugas yang antara lain berupa tugas yang harus diselesaikan pada saat itu juga umpamanya menyusun resume hasil diskusi. Kegiatan ini dimaksudkan untuk mengidentifikasi hasil pembelajaran para peserta didik yang dicapai melalui kegiatan diskusi tersebut.Dengan demikian, pemberian tugas ini sekaligus dapat berfungsi sebagai umpan-balik (feedback).Feedback ini sangat diperlukan guru untuk dijadikan bahan pertimbangan dalam menggunakan metode ceramah plus itu lagi atau metode lainnya yang dipandang lebih pas dengan materi pelajaran yang akan disajikan pada sesi-sesi selanjutnya. ${ }^{8}$

Jadi, dalam pelaksanaan metode ini yang pertama-tama harus dilakukan oleh seorang guru yaitu memberikan penjelasan mengenai pokok bahasan dan topik atau agenda masalah yang akan didiskusikan. Tahap selanjutnya yaitu memberikan kesempatan kepada peserta didik untuk melakukan diskusi, dan tahap terakhir yaitu memberikan tugas misalnya

\footnotetext{
${ }^{7}$ Muhibbin Syah, op. cit., h. 212.

${ }^{8}$ Ibid. h. 212.
} 
tugas resume mengenai topik yang didiskusikan.

3. Metode Ceramah Plus Demonstrasi dan Latihan(CPDL)

Dilihat dari sudut namanya, metode ceramah plus ketiga ini merupakan kombinasi antara kegiatan menggunakan materi pelajaran dengan kegiatan memperagakan dan latihan (drill). Metode CPDL ini sangat berguna bagi proses belajar mengajar bidang studi atau materi pelajaran yang berorientasi pada keterampilan jasmaniah (kecakapan ranah karsa) peserta didik. Walaupun demikian, sebelum para peserta didik mempelajari/melatih kecakapan ranah karsa, terlebih dahulu mereka perlu mempelajari/melatih kecakapan ranah cipta mereka berupa pemahaman mengenai konsep, proses, dan kiat melakukan keterampilan ranah karsa tersebut.

Oleh karena itu, aplikasi metode ceramah plus diskusi dan latihan ini, kurang lebih sama dengan aplikasi metode CPDT, yaitu harus dilakukan secara tertib sesuai dengan urutannya. Namun jika diperlukan, guru dapat memberi ceramah singkat berupa penjelasan tambahan seusai latihan.

Tujuan utama ceramah dalam metode ceramah plus ini adalah untuk menjelaskan konsep-konsep keterampilan jasmaniah yang terdapat dalam materimateri pelajaran keterampilan tertentu, seperti: seni tari, seni suara, dan olah raga. Selain itu, ceramah dalam konteks metode ceramah plus CPDL ini dapat pula digunakan untuk menjelaskan keterampilan praktis yang ada dalam pelajaran agama (Islam), umpamanya keterampilan berwudu dan shalat.

Selanjutnya, tujuan demonstrasi dalam metode CPDL adalah untuk memperagakan atau mempertunjukkan kiat dan proses melakukan keterampilan yang telah diuraikan sebelumnya, yakni pada tahapan ceramah tadi. Dalam mendemonstrasikan keterampilan tersebut, guru dapat dibantu atau diikuti oleh satu atau dua orang peserta didik (sebaiknya putra-putri).Sementara itu, peserta didik-peserta didik lainnya memperhatikan demonstrasi secara seksama.

Tahap terakhir aplikasi metode CPDL adalah penyelenggaraan latihan yang berulang-ulang (drill), yakni latihan keterampilan yang sebelumnya telah didemonstrasikan seperti tersebut tadi. Latihan dalam hal ini dianggap sangat penting, karena menurut low of exercise (hukum latihan), semakin sering sebuah perilaku dilatih atau digunakan maka akan semakin mantap eksistensi perilaku tersebut (Hilgard \& Bowerd, 1975).

Metode latihan umumnya digunakan untuk memperoleh suatu ketangkasan atau keterampilan dari bahan yang dipelajarinya.Karena itu, metode ceramah dapat digunakan sebelum maupun sesudah latihan dilakukan. Tujuan dari ceramah untuk memberikan penjelasan kepada peserta didik mengenai bentuk keterampilan tertentu yang akan dilakukannya.

Ada beberapa prinsip pokok yang perlu diperhatikan guru dalam menyelenggarakan latihan.

a. Latihan itu harus selalu didahului atau diselingi dengan penjelasan guru mengenai dasar pemikiran dan arti penting yang terkandug dalam keterampilan yang sedang dilatihkannya.

b. Latihan itu tidak membosankan peserta didik, oleh karenanya alokasi waktu yang singkat adalah lebih baik.

c. Latihan itu harus menarik perhatian dan minat peserta didik serta menumbuhkan motif peserta didik untuk berpikir, karena menurut Jean Piaget, seorang peserta didik selalu berpikir selama ia berbuat. ${ }^{9}$

Jadi metode yang satu ini sangat cocok untuk pelajaran agama Islam

\footnotetext{
${ }^{9}$ Syaiful Bahri Djamarah, Aswan Zain,
} op. cit., h. 103. 
seperti materi shalat, wudhu dan tayammum.Dengan metode ini, peserta didik diharapkan mampu mempraktekkan misalnya praktek wudhu karena sebelumnya sudah diberikan contoh dalam metode demonstrasi oleh guru atau peserta didik yang ditunjuk untuk mendemonstrasikannya. Kemudian diberi penguatan melalui metode drill atau latihan secara berulang-ulang sampai peserta didik mampu mempraktekkannya dengan baik.

4. Metode Ceramah Plus Demonstrasi dan Eksperimen

Penggunaan metode demonstrasi selalu diikuti dengan eksperimen. Apapun yang didemonstrasikan, baik oleh guru maupun oleh peserta didik (yang dianggap mampu untuk melakukan demonstrasi), tanpa diikuti dengan eksperimen tidak akan mencapai hasil yag efektif. Dalam melaksanakan demonstrasi, seorang demonstrator menjelaskan apa yang akan didemonstrasikan (biasanya suatu proses), sehingga semua peserta didik dapat mengikuti jalannya demonstrasi tersebut dengan baik.

Metode eksperimen adalah metode yang peserta didiknya mencoba mempraktekkan suatu proses tersebut, setelah melihat/mengamati apa yang telah didemonstrasikan oleh seorang demonstrator. Eksperimen dapat juga dilakukan untuk membuktikan kebenaran sesuatu, misalnya menguji sebuah hipotesis.Dalam pelaksanaannya, metode demonstrasi kemudian diikuti eksperimen dengan disertai penjelasan secara lisan (ceramah). ${ }^{10}$

Jadi, metode yang satu ini hampir sama dengan metode ceramah plus demonstrasi dan drill. Hanya saja dalam metode ini peserta didik hanya mencoba mempraktekkan suatu proses setelah melihat apa yang telah didemonstrasikan (Metode Eksperimen). Eksperimen dapat juga dilakukan untuk membuktikan

${ }^{10}$ Syaiful Bahri Djamarah, Aswan Zain, op. cit., h. 99-100.

kebenaran sesuatu.Sedangkan metode yang sebelumnya, langsung memberikan drill atau latihan untuk mempraktekkan yang telah didemonstrasikan.

5. Metode Ceramah Plus Sosiodrama dan Diskusi

Sebelum metode sosiodrama digunakan, terlebih dahulu harus diawali dengan penjelasan dari guru tentang situasi sosial yang akan didramatisasikan oleh para pemain/pelaku. Tanpa diberikan penjelasan, anak didik tidak akan dapat melakukan peranannya dengan baik. Karena itu, ceramah mengenai masalah sosial yang akan didemonstrasikan penting sekali dilaksanakan sebelum melakukan sosiodrama.

Sosiodrama adalah sandiwara tanpa naskah (script) dan tanpa latihan terlebih dahulu, sehingga dilakukan secara spontan.Masalah yang didramatisasikan adalah mengenai situasi sosial. Sosiodrama akan menarik bila pada situasi yang sedang memuncak, kemudian dihentikan. Selanjutnya diadakan diskusi, bagaimana jalan cerita seterusnya, atau pemecahan masalah selanjutnya.

Jadi, metode ini memberikan peluang kepada peserta didik untuk ber sandiwara tanpa naskah (script) dan tanpa latihan terlebih dahulu, sehingga dilakukan secara spontan.Tapi sebelumnya harus dikuatkan melalui ceramah oleh guru agar peserta didik dapat melakukan perannya dengan baik. Setelah melakukan sosiodrama akan dilakukan diskusi mengenai masalah yang sudah disosiodramakan.

6. Metode Ceramah Plus Problem Solving dan Tugas

\begin{tabular}{lcr}
\multicolumn{1}{c}{ Pada } & saat guru memberikan \\
pelajaran kepada peserta didik, & da \\
adakalanya & timbul & suatu \\
persoalan/masalah yang tidak dapat \\
diselesaikan dengan hanya penjelasan \\
secara lisan melalui ceramah.Untuk itu \\
guru perlu menggunakan metode \\
pemecahan masalah atau problem
\end{tabular}


solving, sebagai jalan keluarnya.Kemudian diakhiri dengan tugas-tugas, baik individu maupun tugas kelompok, sehingga peserta didik melakukan tukar pikiran dalam memecahkan masalah yang dihadapinya.Metode ini banyak menimbulkan kegiatan belajar peserta didik yang lebih optimal. ${ }^{11}$

Jadi, dalam penggunaan metode ini peserta didik diberikan kesempatan untuk memecahkan masalahnya sendiri yang timbul dalam proses pembelajaran. Tapi sebelumnya guru menguraikan materi ajar melalui metode ceramah sehingga memunculkan masalah yang dianggap perlu untuk dipecahkan secara bersama-sama oleh peserta didik sehingga mereka mampu berpikir kritis.Kemudian, guru memberikan tugas akhir seperti membuat kesimpulan pemecahan masalah.

Akhirnya, selain kombinasi sebagaimana disebutkan di atas, masih terbuka kemungkinan adanya kombinasi yang lain. Bahkan tidak mustahil metode pembelajaran dapat untuk dua atau empat metode pembelajaran.

\section{Penutup}

Melihat pendidikan hari ini mengalami kemunduran dari segi kualitas seharusnya seorang pendidik mampu memahami itu dan mampu mengatasi masalah pembelajaran yang tidak efektif.Pendidik memiliki memiliki peran yang sangat besar terhadap tercapainya tujuan pendidikan. Pendidik berperan penting dalam pemberian motivasi kepada peserta didik dan mengefektifkan proses pembelajaran agar tujuan pembelajaran yang diharapkan dapat tercapai. Untuk itu, seorang pendidik harus memiliki keempat kompetensi yang ada yaitu kompetensi pedagogik, kepribadian, sosial dan profesional. Kompetensi guru dari hari kehari harus terus di update sesuai perkembangan zaman terutama dalam penggunaan metode pembelajaran yang lebih variatif agar peserta didik tidak mengalami kejenuhan dalam pembelajaran ketika guru hanya menggunakan saru metode saja (monoton).

\footnotetext{
${ }^{11}$ Ibid., h. 102.
} 


\section{DAFTAR PUSTAKA}

Bahri Djamarah, Syaiful. Psikologi Belajar. Cet. I, Jakarta: RINEKA CIPTA, 2002.

Bahri Djamarah,Syaiful. Aswan Zain.Strategi Belajar Mengajar. Cet. III, Jakarta: PT. Rineka Cipta, 2006.

Daradjat, Zakiah dkk.Ilmu Pendidikan Islam. Cet. IV; Jakarta: Bumi Aksara, 2000.

Gintings, Abdorrakhman. Esensi Praktis Belajar \& Pembelajaran. Cet. II; Bandung: Humaniora, 2008.

Hamalik, Oemar. Pendidikan Guru: Berdasarkan Pendekatan Kompetensi. Cet. III; Jakarta: PT Bumi Aksara, 2004.

Irianto, Yoyon Bahtiar. Kebijakan Pembaruan Pendidikan: Konsep, Teori dan Model. Cet. II; Jakarta: PT Rajagrafindo Persada, 2012.

Muhibbin, Syah. Psikologi Pendidikan dengan Pendekatan Baru.Cet: VIII; Bandung: PT. Remaja Rosdakarya, 2003.

Mulyasana, Dedi. Pendidikan Bermutu dan Berdaya Saing. Cet. II; Bandung: PT Remaja Rosdakarya, 2012.

Prawiradilaga, Dewi Salama. Prinsip Disain Pembelajaran (Instructional Design Principles). Cet. III; Jakarta: Kencana Prenada Media Group, 2009.

Republik Indonesia.Undang-Undang Sistem Pendidikan Nasional No. 20 Tahun 2003. Jakarta: Sinar Grafika, 2003.

Sabri, Ahmad. Strategi Belajar Mengajar \& Micro Teaching. Cet. II, Padang: PT. Ciputat Press, 2007.

Sagala, Syaiful. Kemampuan Profesional Guru dan Tenaga Kependidikan. Cet. I, Bandung: CV. Alfabeta.

Surachmad, Winarno.Metodologi Pengajaran Nasional. Bandung: CV. Jemmars.

Suyono dan Hariyanto. Belajar dan Pembelajaran: Teori dan Konsep Dasar. Cet. III; Bandung: PT Remaja Rosdakarya Offset, 2012.

Tim Penyusun Kamus. Kamus Besar Bahasa Indonesia. Cet. III; Jakarta: Balai Pustaka, 2003. 